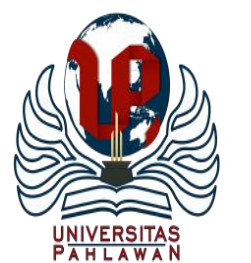

Edukatif : Jurnal Ilmu Pendidikan Volume 3 Nomor 2 Tahun 2021 Halm 270 - 277

EDUKATIF: JURNAL ILMU PENDIDIKAN

Research \& Learning in Education

https://edukatif.org/index.php/edukatif/index

\title{
E-Learning System For Physical Education In IAIN Salatiga Using Google Classroom
}

\author{
Fatkhur Rozi ${ }^{1 凶}$, Mega Widya Putri², M. Riski Adi Wijaya ${ }^{3}$ \\ IAIN Salatiga, Indonesia ${ }^{1}$ \\ Universitas Muhammadiyah Pekajangan Pekalongan, Indonesia ${ }^{2,3}$ \\ E-mail : fatkhur21@iainsalatiga.ac.id ${ }^{1}, \underline{\text { megawidyaputri@umpp.ac.id }}{ }^{2}, \underline{\text { riskiadi@umpp.ac.id }}^{3}$
}

\begin{abstract}
Abstrak
Penelitian ini bertujuan untuk menganalisis proses perkuliahan teori dan praktek pendidikan jasmani di Institut Islam Negeri Salatiga (IAIN Salatiga) dengan menggunakan media google clasroom. Metode yang digunakan adalah kualitatif dengan pendekatan fenomenologi dan desain studi kasus untuk mengkaji secara mendalam aspek-aspek yang mempengaruhi penggunaan media google classroom dalam pembelajaran pendidikan jasmani. Hasil dari penelitian ini adalah e-learning pendidikan jasmani menggunakan google classroom di IAIN Salatiga dapat digunakan sebagai solusi atas keterbatasan waktu dalam pembelajaran pendidikan jasmani. Selanjutnya memudahkan dosen dalam menyampaikan materi pendidikan jasmani dan memudahkan mahasiswa dalam mempelajari materi pendidikan jasmani. Akses sinyal internet menjadi kendala utama dalam e-learning pendidikan jasmani menggunakan google classroom di IAIN Salatiga.
\end{abstract}

Kata Kunci: e-leraning, google classroom, media pembelajaran, pendidikan jasmani.

\begin{abstract}
This study aims to analyze the process of lecturing the theory and practice of physical education at the Salatiga State Islamic Institute (IAIN Salatiga) using the google clasroom media. The method used is qualitative with a phenomenological approach and case study design to examine in depth the aspects that influence the use of google classroom media in the physical education learning. The results of this study are the physical education e-learning using google classroom at IAIN Salatiga can be used as a solution to the limitations of theoretical and practical in the physical education learning. Furthermore, it makes it easier for lecturers to deliver physical education material and makes it easier for students to learn physical education material. Internet signal access is a major obstacle in e-leraning physical education using google classroom at IAIN Salatiga.
\end{abstract}

Keywords: e-learning, google classroom, learning media, physical education.

Copyright (c) 2021 Fatkhur Rozi , Mega Widya Putri, M. Riski Adi Wijaya

$\triangle$ Corresponding author

Email : fatkhur21@iainsalatiga.ac.id

DOI : https://doi.org/10.31004/edukatif.v3i2.268

ISSN 2656-8063 (Media Cetak)

ISSN 2656-8071 (Media Online)

Edukatif : Jurnal Ilmu Pendidikan Vol 3 No 2 Tahun 2021

p-ISSN 2656-8063 e-ISSN 2656-8071 
271 E-Learning System For Physical Education In IAIN Salatiga Using Google Classroom - Fatkhur Rozi, Mega Widya Putri, M. Riski Adi Wijaya

DOI: https://doi.org/10.31004/edukatif.v3i2.268

\section{INTRODUCTION}

The development of education in Indonesia from time to time experiences various dynamics of positive change in various ways. However, the development of education in Indonesia is still experiencing shortages in various sectors, including educational facilities and infrastructure, not yet optimal use of technological sophistication, and the still lack of quality human resources that have an impact on the quality of education in Indonesia. The success of education in Indonesia is a serious challenge in the current era of globalization.

The government has provided educational institutions, ranging from early childhood education to higher education in order to improve human resources in Indonesia. Higher education has a very important role in increasing human resources that will compete in the global world. For this reason, education in tertiary institutions is demanded to continue to innovate and improve the competence of both scholars and lecturers.

IAIN Salatiga is one of the state Islamic higher education institutions that has a role in improving the quality of human resources, including: the quality of employees, lecturers, and scholars who are good, superior, and of good character. IAIN Salatiga has several excellent Study, one of which is the Madrasah Ibtidaiyah Teacher Education Study (PGMI). In order to prepare qualified prospective Madrasah Ibtidaiyah (MI) teachers, the lecture process is strived to run well. However, in Physical Education courses (PE), there are still some obstacles. The obstacle that was found was the lecture time which was only 2 credits with a duration of 2 X 50 minutes. While in Physical Education itself cannot be separated between the unity of theoretical and practical material. Physical education at the university itself is 3 hours long, which is equivalent to $3 \times 45$ minutes. This certainly makes the problem of lack of lecture time in the theory and practice of education in PGMI IAIN Salatiga Study.

PGMI Study which is the superior study program at IAIN Salatiga has many scholars. The PGMI Study scholars in the observation of researchers, on average already have a gadget in the form of a portable computer or mobile phone. However, so far it has not been touched to be used as a learning medium in Physical Education (PE). Supposedly, this can be used as an answer to the problem of the limited lecture theories and Physical Education practices. As we know, there are many available online platforms that provide media for online learning. One such media is Google Classroom.

The existence of online learning media can be used in Physical Education lectures to provide innovation. Usually, lectures or professors of Physical Education have a tendency to use the same method to teach Physical Education (Kristianto \& Margono, 2005). Previously, this had never been done in a physical education course. In research conducted in other courses, this has been done with the result that online applications can help lecturers with scholars (Rozak \& Albantani, 2018). Google Classroom is one of the media that can be used as learning media 4.0 (Savitri, 2019). However, in its use must understood about the factors that influence (Wijaya, 2016).

Some background above shows that Google Classroom can be used as an online learning, but it still needs to be considered factors that can influence its use. This research is related to this matter, where in this research that focuses on an in-depth study has been carried out related to the influencing factors and limitations in the implementation of Google Classroom in the theoretical and practical education courses at IAIN Salatiga. The purpose of this research is to analyze the use of Google Classroom in Physical Education lectures at IAIN Salatiga. This research has been carried out in PGMI Study towards classes A, B, C, D, and E in odd semester of 2019/2020. 
272 E-Learning System For Physical Education In IAIN Salatiga Using Google Classroom - Fatkhur Rozi, Mega Widya Putri, M. Riski Adi Wijaya

DOI: https://doi.org/10.31004/edukatif.v3i2.268

\section{METHODS}

This research uses a qualitative method with a phenomenological approach to observe phenomena naturally. This research uses a case study design to conduct in-depth research related to the use of Google Classroom media in the Physical Education lecture at IAIN Salatiga. The focus of this research is related to aspects that influence and solutions in the use of Google Classroom media in the Physical Education lecture at IAIN Salatiga.

Primary data of this research are the results of online interviews and field observations. Secondary data sources are documents and archives related to physical education lectures at IAIN Salatiga. The subjects of this study were students of IAIN Salatiga who attended physical education lectures. Data collection instrument using: interview guidelines, observation guidelines, and study sheets documentation. Validity testing of the data was done by method triangulation. The data analysis method used in this study is a model analysis of Miles and Huberman.

\section{RESULTS AND DISCUSSION}

This research was The research has been conducted at the Salatiga IAIN PGMI Study Program in A, B, $\mathrm{C}, \mathrm{D}$ and $\mathrm{E}$ classes for one semester. The details of the research activities that have been carried out are as follows:

Table 1. Details of Research Activities

\begin{tabular}{ll}
\hline Activity & Stages Activity \\
\hline $\begin{array}{l}\text { Using e-learning for physical education in } \\
\text { theory materials }\end{array}$ & $\bullet$ Choose the aplications for e-learning. \\
& $\bullet$ Create user manuals for running e-learning \\
& applications \\
& $\bullet$ Provide training on how to use e-leraning \\
& $\bullet$ Evaluation. \\
\hline The socialization and publication of the & $\bullet$ Socialization planning \\
Physical Education implementation e- & $\bullet$ Preparation for socialization \\
learning & $\bullet$ Implementation \\
& $\bullet$ Evaluation \\
\hline Evaluation and writing of the Physical & $\bullet$ Mapping of evaluation aspects \\
Education implementation e-learning report & $\bullet$ Evaluation \\
& $\bullet$ Make solutions to evaluations made \\
& $\bullet$ Compiling evaluation reports and actualization \\
& activities
\end{tabular}

Table 2. Using E-Learning for Physical Education

\begin{tabular}{ll}
\hline Activity & $\begin{array}{l}\text { Using e-learning for physical education in theory } \\
\text { materials }\end{array}$
\end{tabular}

DESCRIPTION OF ACTIVITIES The first activity: the use of e-learning in the physical education theory material 
273 E-Learning System For Physical Education In IAIN Salatiga Using Google Classroom - Fatkhur Rozi, Mega Widya Putri, M. Riski Adi Wijaya

DOI: https://doi.org/10.31004/edukatif.v3i2.268

\begin{tabular}{ll}
\hline Location & FTIK IAIN SALATIGA \\
\hline Stages Activity & $\bullet$ Choose the aplications for e-learning. \\
& $\bullet$ Create user manuals for running e-learning \\
& applications \\
& $\bullet$ Provide training on how to use e-leraning \\
& $\bullet$ Evaluation. \\
\hline Obstacle and Strategy & $\bullet$ Obstacles : the internet signal is slowly when \\
& sozialitation process \\
& $\bullet$ Strategy: Give the tethering internet system \\
\hline Output & E-learning documents \\
\hline
\end{tabular}

Table 3. Using E-Learning for Physical Education

Activity Lecture optimalization

DESCRIPTION OF ACTIVITIES Second activity: socialization and publication of the e-learning physical education

\begin{tabular}{ll}
\hline DATE & 23 - 30 November 2019 \\
\hline Location & FTIK IAIN SALATIGA \\
\hline Stages Activity & - Socialization planning \\
& - Preparation for socialization \\
& - Implementation \\
& - Evaluation \\
\hline Obstacle and Strategy & Obstacles : The low interest of people towards \\
& physical education \\
& - Strategy: Using youtube and whats app \\
& aplication for publication \\
\hline Output & Chanel youtube \\
\hline
\end{tabular}

Table 4. Evaluation and Writing of The Physical Education Implementation E-Learning Report

\begin{tabular}{ll}
\hline Activity & Evaluation of Activities \\
\hline DESCRIPTION OF ACTIVITIES & $\begin{array}{l}\text { Third activity: Evaluation of The Physical } \\
\text { Education E-learning }\end{array}$ \\
\hline DATE & 1-3 December 2019 \\
\hline location & FTIK IAIN SALATIGA \\
\hline Stages Activity & - Mapping of evaluation aspects \\
& - Evaluation \\
& - Make solutions to evaluations made \\
& - Compiling evaluation reports and actualization \\
& activities \\
\hline Obstacle and Strategy & - Obstacles: The limited time for evaluation \\
& - Strategy: Perform an evaluation with an online \\
& questionnaire \\
\hline Output & The online questionnaire data \\
\hline
\end{tabular}

E-learning is internet-based learning where there are no face-to-face meetings between lectures and scholars. Teaching and learning not only occur in real classrooms but also in virtual classrooms, where lectures and scholars are physically separated. However, the term e-learning can not be equated with distance learning, even though both do not require face to face. But the reality is that distance education in most higher education systems is not delivered through new electronic media, and conversely electronic learning in most 
274 E-Learning System For Physical Education In IAIN Salatiga Using Google Classroom - Fatkhur Rozi , Mega Widya Putri, M. Riski Adi Wijaya

DOI: https://doi.org/10.31004/edukatif.v3i2.268

universities and colleges around the world is not used for distance education purposes (Guri \& Rosenbilt, 2005). There are different hopes and perceptions of the learning environment label: distance learning, elearning, and online learning (Moore et al., 2011). In the past decade, there has been tremendous growth in the availability of colleges and universities programs that are taught entirely online (Bacelar-Nicolau et al., 2009). This research is an e-learning research in Physical Education as explained in tables 1, 2, and 3. E-learning is conducted using Google Classroom.

E-learning becomes a popular tool as an interactive tool for virtual education (Darmayanti et al., 2007). The implementation of e-learning is supported by learning systems, learning assessments, and operational service support systems (Sefriani \& Sepriana, 2020). Physical Education e-learning at IAIN Salatiga is one of the solutions to solving the problem of time constraints in lectures and facilitating the theoretical learning of Physical Education. The following survey results are used as a basis:

E-Learning Penjas sebagai salah satu solusi alokasi waktu yang kurang pada kuliah/pembelajaran teori dan praktik dalam Penjas

89 responses

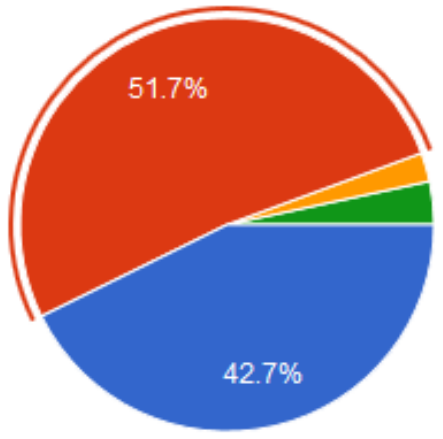

5. Sangat Setuju

4. Setuju

3.Kurang Setuju

2. Tidak Setuju

1. Sangat Tidak Setuju

Figure 1. The Result of E-Learning Physical EducatioHasil Survey

E-Learning Penjas menjadikan belajar teoritik pada Penjas dapat dilakukan kapan saja dan dimana saja

89 responses

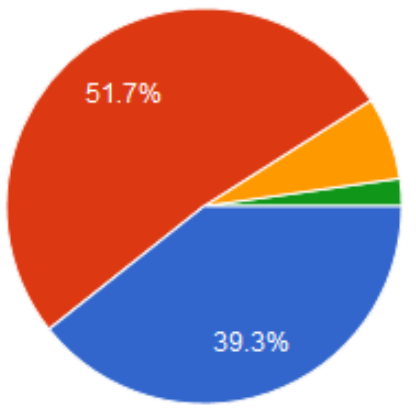

5. Sangat Setuju

4. Setuju

3.Kurang Setuju

2. Tidak Setuju

1. Sangat Tidak Setuju

Figure 2. The Result of Theoritical Physical Education survey 
275 E-Learning System For Physical Education In IAIN Salatiga Using Google Classroom - Fatkhur Rozi, Mega Widya Putri, M. Riski Adi Wijaya

DOI: https://doi.org/10.31004/edukatif.v3i2.268

The use of gadgets in Physical Education e-learning allows lecturers to more easily communicate with their scholars while learning Physical Education materials. This is according to Korucu \& Alkan's explanation: "The features of mobile devices that allow the educational atmosphere encourage individuals to use it. In addition, it allows educators who share information to contact more students regardless of time and location with the use of mobile devices in education" (Korucu, Agah Tugrul., 2011). This e-learning is the answer to innovation in Physical Education lectures. E-learning changes the way of teaching (educators), learning (students), and innovation (learning) (Jatira \& Neviyarni, 2021). The development of e-learning systems has started a revolution for the delivery of learning content, learning activities, and social communication (Calli et al., 2013). However, e-learning does not have a significant impact on learning achievement outcomes (Al-Qahtani \& Higgins, 2012).

There must be obstacles on impementing e-learning. One scientific source states that there are problems in e-learning. The implementation of e-learning based on learning systems also still faces problems, including: institutional readiness issues, instructor readiness issues, student readiness issues, investment cost issues, technology issues, infrastructure problems, and learning material issues (Sutanta, 2015). Previous research on e-learning in mathematics found the results of e-learning constraints, namely: the constraints of human resources (teachers and students) and the facilities and infrastructure factors (electronic devices and internet access) (Umi Haniah, 2012). The obstacle faced by Physical Education e-learning at IAIN is in internet signal access (table 1). This is supported by the following survey data:

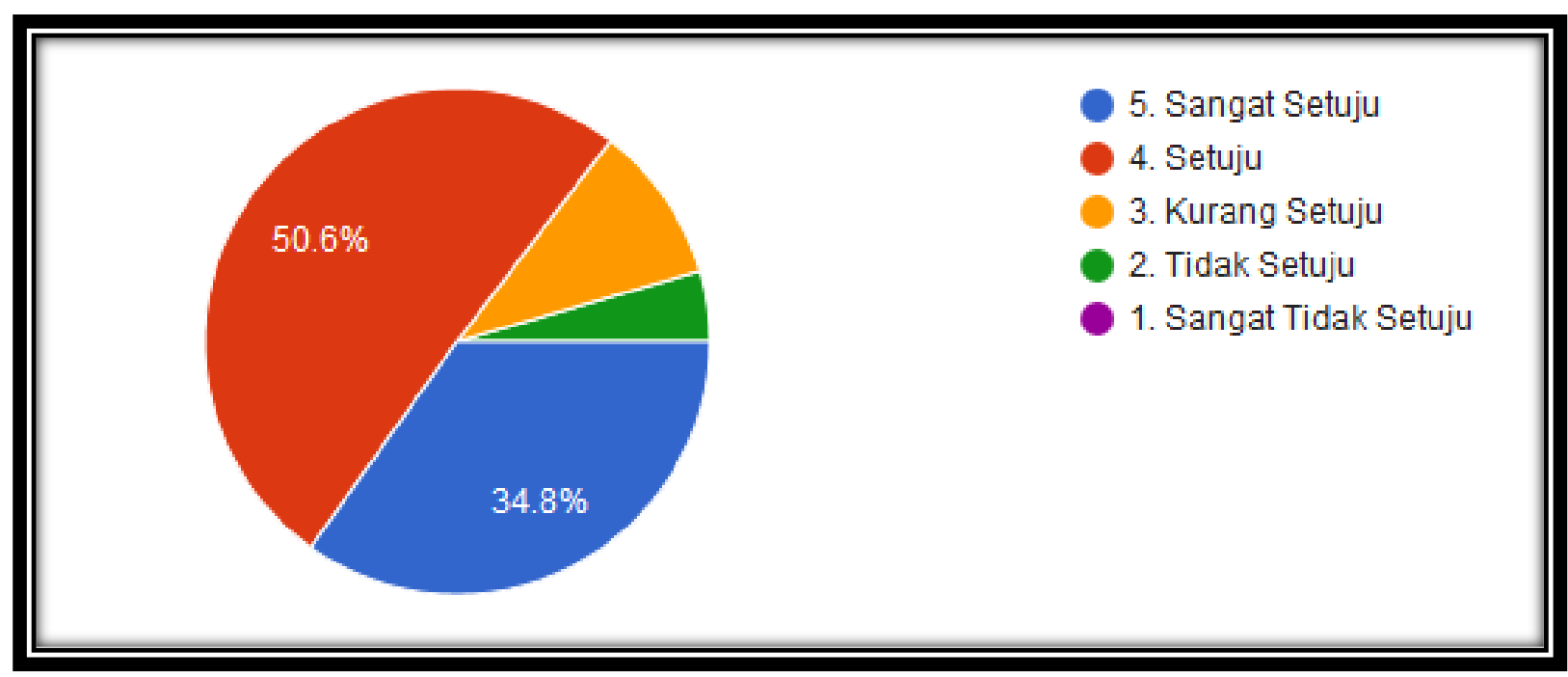

Figure 3. The Result of Obstacle in E-Learning Physical Education

Based on the picture above, when the researchers conducted a survey with the question "Is internet signal a major obstacle in e-learning Physical Education?" The results of the survey are $50.6 \%$ answered strongly agree and $34.8 \%$ answered agree. The survey was filled by all PGMI IAIN Salatiga scholars in class A, B, C, D, and E odd semester 2019/2020. Furthermore, the data is used as a reinforcement of observations that researchers have made. Physical Education e-learning at IAIN Salatiga is only implemented for theoretical material, whereas practical material is implemented directly in the field. This is because of practical materials needed direct visualization in order to facilitate scholars more easily understand the material provided. In addition, social contact and direct communication are also needed as an intact dimension of the Physical Education lecture process.

The development of Physical Education e-learning is expected to be able to realize the achievement of Physical Education learning objectives. Physical Education learning goal categories according to Bucher, namely: physical development, movement development, mental development, and social development 
276 E-Learning System For Physical Education In IAIN Salatiga Using Google Classroom - Fatkhur Rozi, Mega Widya Putri, M. Riski Adi Wijaya

DOI: https://doi.org/10.31004/edukatif.v3i2.268

(Permana, 2020). Physical Education e-learning is present to provide extended time for Physical Education classes at IAIN Salatiga. So that one of the Physical Education goals is to improve scholars fitness can be achieved. Fitness/physical fitness is a problem that is being faced by our society. Based on 2006 SDI data, it shows that the fitness condition of our society: $1.08 \%$ is categorized as the excellent category; $4.07 \%$ good; $13.55 \%$ moderate; $43.90 \%$ less; and $37.40 \%$ less (Darmawan, 2017).

\section{CONCLUSION}

The conclusion of this research is the Physical Education e-learning using Google Classroom at IAIN Salatiga can be used as a solution to the limited time of theoretical and practical lectures. Furthermore, it makes easier for lecturers to deliver Physical Education materials and makes it easier for scholars to learn Physical Education materials. Internet signal access is the main problem in e-leraning Physical Education using Google Classroom at IAIN Salatiga. Future research is expected to be able to review the making of the Physical Education lecture e-module to support the materials in the e-learning application.

\section{ACKNOWLEDGEMENT}

We thank to Department for Research and Community Service IAIN Salatiga for the research opportunity.

\section{REFERENCES}

Al-Qahtani, A. A. Y. ., \& Higgins, S. E. (2012). Effects of traditional, blended and e-learning on students' achievement in higher education. Journal of Computer Assisted Learning, 29(3), 220-234. https://doi.org/10.1111/j.1365-2729.2012.00490.x

Bacelar-Nicolau, P., Caeiro, S., Martinho, A. P., Azeiteiro, U. M., \& Amador, F. (2009). E-learning for the environment: The Universidade Aberta (Portuguese Open Distance University) experience in the environmental sciences post-graduate courses. International Journal of Sustainability in Higher Education, 10(4), 354-367. https://doi.org/10.1108/14676370910990701

Calli, L., Balcikanli, C., Calli, F., Cebeci, H. I., \& Seymen, O. F. (2013). Identifying factors that contribute to the satisfaction of students in e-learning. Turkish Online Journal of Distance Education, 14(1), 85-101. https://doi.org/10.17718/tojde.36824

Darmawan, I. (2017). UPAYA MENINGKATKAN KEBUGARAN JASMANI SISWA MELALUI PENJAS. JIP [Internet], 7(2), 143-154. http://ejournal.unikama.ac.id/index.php/jrnspirasi/article/view/1700

Darmayanti, T., Setiani, M. Y., \& Oetojo, B. (2007). E-Learning Pada Pendidikan Jarak Jauh: Konsep Yang Mengubah Metode Pembelajaran Di Perguruan Tinggi Di Indonesia. Jurnal Pendidikan Terbuka Dan Jarak Jauh, 8, 99-113.

Guri, S., \& Rosenbilt. (2005). 'Distance education' and 'e-learning': Not the same thing. High Educ, 49, 467493. https://doi.org/10.1007/s10734-004-0040-0

Jatira, Y., \& Neviyarni, S. (2021). Fenomena Stress dan Pembiasaan Belajar Daring dimasa Pandemi Covid19. Edukatif: Jurnal Ilmu Pendidikan, 3(1), 35-43. https://www.edukatif.org/index.php/edukatif/article/view/187

Korucu, Agah Tugrul., A. A. (2011). Differences between m-learning (mobile learning) and e-learning, basic terminology and usage of m-learning in education. Procedia - Social and Behavioral Sciences, 15, 19251930. https://doi.org/10.1016/j.sbspro.2011.04.029 
277 E-Learning System For Physical Education In IAIN Salatiga Using Google Classroom - Fatkhur Rozi , Mega Widya Putri, M. Riski Adi Wijaya

DOI: https://doi.org/10.31004/edukatif.v3i2.268

Kristianto, A., \& Margono, A. (2005). Peningkatan Kompetensi Mengajar Pendidikan Jasmani Melalui Perbaikan Pilihan Spektrum Gaya Mengajar (The Spectrum of Teaching Style). Jurnal Ilmu Pendidikan: Jurnal Kajian Teori Dan Praktik Kependidikan, 32(5).

Moore, J. L., Dickson-Deane, C., \& Galyen, K. (2011). E-Learning, online learning, and distance learning environments: Are they the same? Internet and Higher Education, 14(2), 129-135. https://doi.org/10.1016/j.iheduc.2010.10.001

Permana, R. (2020). TEORI DAN PRAKTIK: PENDIDIKAN JASMANI DI PERGURUAN TINGGI (Zulfikar (ed.)). Edu Publisher.

Sefriani, R., \& Sepriana, R. (2020). Pengembangan Media E-Learning Berbasis Schoology pada Pembelajaran Kurikulum Pendidikan Teknologi dan Kejuruan. Edukatif: Jurnal Ilmu Pendidikan, 2(1), 8-14. https://www.edukatif.org/index.php/edukatif/article/view/76/pdf

Sutanta, E. (2015). Konsep dan Implementasi E-Learning ( Studi Kasus Pengembangan E- Learning di SMA N 1 Sentolo Yogyakarta ). Studi Kasus Pengembangan E-Learning, June 2009, 1-16. https://www.researchgate.net/publication/235525803

Umi Haniah, N. A. (2012). Faktor Kendala Sekolah Yang Akan Menerapkan E-Learning Pada Pembelajaran Matematika (Studi Kasus di MTs Negeri Pakem, Sleman, Yogyakarta). http://eprints.ums.ac.id/19290/

Wijaya, A. (2016). Analysis of factors affecting the use of google classroom to support lectures. The 5th International Conference on Information Technology and Engineering Application, 61-68. http://eprints.binadarma.ac.id/2777/ 